\title{
The Strategy of Education and Training During The Covid-19 Pandemic
}

\author{
Bayu Adi Laksono \\ Faculty of Teacher Training and Education, Universitas Siliwangi \\ email: bayu.adi@unsil.ac.id
}

\begin{abstract}
Received: 27 March 2021; Revised: 06 June 2021; Accepted: 28 August 2021
DOI: http://dx.doi.org/10.37905/aksara.7.3.855-864.2021
\end{abstract}

\begin{abstract}
The purpose of this research is to find out how to manage education and training strategies that not only maintain the existence of the institution but also provide benefits for the perpetrators even though it is carried out during the pandemic. This research was conducted in 6 courses and training institutions in East Java and West Java, from March to April 2021. Using a qualitative approach, starting with the distribution of a preliminary questionnaire, then elaborated by in-depth interviews. The results of the study show that the pandemic provides fundamental changes to the governance or management of educational and training institutions starting from planning, implementation and evaluation. At the planning stage, the course and training institutions change the time, goals, and costs to adapt to pandemic conditions, then create digital marketing strategies, and initial assessments for material efficiency. At the implementation stage, the institution applies virtual learning, as well as face-to-face meeting if it is really necessary to do so. At the evaluation stage, the institution uses a contextual evaluation adapted to the pandemic situation but with the appropriate conditions.
\end{abstract}

Keywords: Education, Training, Pandemic

\section{INTRODUCION}

Unforeseen conditions at the beginning of 2020 due to Covid-19 impacted all activities. The COVID-19 pandemic has seriously affected all aspects of activities. Apart from the impacts of the health, the economic, educational, social and cultural are also some of the aspects that are seriously affected. Teaching and learning activities, religious activities, tourism, and activities that have the potential to create crowds have all been suspended by the government. More specifically, very fundamental changes occurred in the education aspect, such as in formal education, namely the closing of schools to universities, which then replaced teaching and learning activities through virtual meeting (online). In addition to formal education, non-formal education channels also change their learning activities which were originally face-to-face to virtual because in principle like educational activities in general, non-formal education also has the potential to create a crowd. Non-formal education units based on government regulations consist of course institutions, training institutions, study groups, community learning activity centers, majelis taklim, and similar educational units. One of the nonformal education units is a training institution. In training institutions, training activities 
that originally required participants to come physically were later replaced with virtual (online) training. Some types of training that do not require technical activities and technical tools in general can be replaced with virtual learning procedures, but some types of training that are technical in nature and use technical tools must impose special activities that can not be replaced with virtual activities.

The results of previous studies stated that the existence of a non-formal educational institution during pandemic can not be separated from qualified management activities and implementing strict and measurable management processes (Pranoto et al., 2021). In addition, strategic planning and support from the government in terms of policies on the use of technology and information in educational activities are ways to prevent the impact of COVID-19 from getting worse after the pandemic (Olagbaju et al., 2020). Based on this situation, the researcher wishes to examine how the education and training management strategy not only maintains the existence of the institution but also provides benefits for the perpetrators even though it is carried out during the pandemic.

\section{METHOD}

This study uses a qualitative approach, with 6 resource persons from the management of training institutions from East Java and West Java. The resource persons consisted of NY (language and computer training institute), CC (art training institute), WW (cosmetology training), AR (personality and ethics training), MG (personality and ethics training), and AM (design and computer training institute). The data collection method used a questionnaire to find out the initial description and then elaborated using depth interviews for more detailed answers. The depth interview process uses an interview guide that has been prepared based on a general study of the management/management of educational and training institutions, namely planning, implementation, and evaluation. In practice, interviews were conducted flexibly and naturally to extract data with a high level of validity. The study was conducted during March to April 2021 by following the health protocol. The research design uses the stages of data collection, triangulation, data selection, data analysis, data exposure, and drawing conclusions.

\section{RESULTS AND DISCUSSION Results}

The interview results show that COVID-19 pandemic has had a tremendous impact on training institutions. This was conveyed by NY as the manager of the language training institution because it was practical after the implementation of the social restriction policy, the institution stopped operating for 7 months. A similar picture was conveyed by $\mathrm{CC}$ who stated that his institution which was engaged in drawing, painting and batik training for children did not operate at all, considering that collaborative activities with several schools had also stopped due to the closure of teaching and learning activities. $\mathrm{CC}$ added that the financial management of the institution had become very severe, starting with the income of almost $0 \%$ to the difficulty in paying off the principal of the loan to the financial institution. WW described the severity of the impact of the pandemic in terms of learning management, which stated that the impact is very significant, ranging from canceled programs to a 
reduction in the number of participants due to the implementation of health protocols. Furthermore, WW revealed that the cooperation program with the government received a reduction in the quota of participants and the implementation became shorter, which resulted in less than optimal implementation of learning although it could still be overcome with various innovations. Information by AR, MG, and AM also stated that their institutions had a significant impact due to the challenges in getting new students, to the interest in training programs which fell by almost half. The decrease in the number of training participants as a result of the COVID-19 pandemic felt by training institutions varied from $50 \%$ to $100 \%$. Signs of a decline in the number of training participants began to be felt by institutional managers starting in March 2020, and the worst was at the time of the implementation of social restriction policies in several regions.

The Covid-19 pandemic has also forced institutional managers to adapt. CC revealed that the pandemic brought changes to the governance of the institution, which initially focused on training in the fields of art and drawing, to other fields of art, namely creative businesses, batik, and products related to works of art. Furthermore, CC revealed that the first thing that needs to be adjusted when facing a pandemic is the readiness of the mindset, which is to always be grateful and think positively. Unlike the previous informants, NY revealed that the changes that occurred were more in internal management, so that the programs within the institution did not change and continued to run but with different methods. NY revealed that the online method was the method he applied to keep the program in his institution running, then interspersed with face-toface health protocols. This is in line with what was expressed by WW. At the institution, WW remains with the existing program but applies a new method. Examples of the methods applied are providing programs with shorter durations and collaborating with the government to provide online-based training programs. AR and MG stated that the main focus in dealing with the pandemic was to use social media for marketing activities, because both of them faced similar problems, namely the drastic decline in training participants.

During the pandemic, training managers faced the same general problem, namely the limited delivery of material due to avoiding face-to-face meetings. The material presented certainly faced many obstacles, one of which was disclosed by NY. NY stated that the face-to-face material transfer process was very ineffective, so that in the end NY continued to use face-to-face learning but by reducing or limiting the number of participants in the room and implementing very strict health protocols so that the planning process in training activities was updated according to health protocols. In line with what was stated by NY, CC stated that all programs to be implemented by his institution were all adjusted to health protocols but still adapted to the needs of the community. A unique thing was conveyed by WW, he stated that the program planning process in the pandemic era went awry. The program, which is supposed to be a community need, is not possible to run because it collides with health protocols, but if it is implemented virtual, the results will not be optimal because the transfer of expertise is disrupted. Even if it is run face-to-face, it will still not be optimal due to limited resources and limited funding due to the pandemic. In the end, WW innovated to create programs that were needed by the community but still affordable due to the accelerated time system. In the planning process of $\mathrm{AR}, \mathrm{MG}$, and AM programs, the focus is more 
on effectiveness and efficiency on what can be done so the program which could run is carried out optimally. In the program implementation plan, of course it requires the dissemination of information or marketing techniques. In general, all training managers in pandemic conditions use an online system by utilizing social media in their marketing activities. Even though there is still distribution of brochures to the training targets on a very limited scale, not more than $10 \%$ of the total marketing activities.

In the program planning stage, training institutions generally select or conduct initial tests aimed at getting an overview of initial abilities, or can also be used as a form of selection due to limited quotas. In this context, $\mathrm{CC}$ stated that in a pandemic condition, there is still an initial assessment as a form of needs analysis even though it must be adjusted to health protocols. In line with the previous statement, NY also conducted an initial assessment but it was used as a form of selection due to the limited quota of participants and of course using health protocols. WW revealed that in the initial assessment process in order to comply with the health protocol, prospective participants must attach a certificate from a doctor stating that the person concerned is in good health. AR and MG stated that the selection process carried out mostly used a virtual system (online) then used face-to-face system if a more detailed assessment was needed. Unlike the previous interviewees, AM stated that in the recruitment process for prospective trainees at his institution there was no selection process, every prospective participant who was interested in practicing was given the opportunity.

The implementation stage in the training program is a fundamental stage, because at this stage technical activities are carried out. In general, training managers during the pandemic use a face-to-face system as well as a blended learning system or a mix of online and offline learning, none of which uses fully online. WW states that when it gets permission from the government to carry out activities, all activities carried out in its institutions use the offline system. This is because the type of training carried out is a type of training that requires more technical activities. Furthermore, WW revealed that in his training activities all participants used health protocols by washing hands, wearing masks, learning was divided into several sessions to avoid crowds, and the duration of the implementation was reduced to half a day. In line with the previous interviewees, NY, AR, MG also implemented a face-to-face or offline training system, this was done because the type of training was very technical and required face-to-face meetings. The training activities carried out by NY, AR, and MG also continue to use health protocols. In contrast to the previous informants who chose to use full face-toface, $\mathrm{CC}$ and $\mathrm{AM}$ chose to use a mixed system, at the initial training or introduction stage and theory they used an online system but in activities that were already in the technical realm, they used face-to-face training. Consideration of the use of online and offline system methods based on the pandemic situation, because basically all managers state that it is more optimal to use face-to-face (offline). Based on the results of interviews with resource persons, the type of training that has its own challenges if carried out online is the type of training that requires a lot of practice because if it is carried out online, controlling the content will be very difficult to do and the impact is reduced skills and has the potential to fail in its implementation. Another type of training that has challenges if it is carried out online is training that aims to increase self-development and motivation because it is limited by the media for fear that the message conveyed will be biased and multi-interpreted. But on the other hand, online 
training system also provides benefits, namely the principle of time efficiency for participants who are far away from the training venue and the principle of health considerations because it has the potential to create new clusters of COVID-19.

The results of the interview regarding the evaluation stage show that the evaluation is carried out in general as before the presence of covid-19, but the difference is that it is currently adjusted to health protocols. NY stated that the evaluation used by its institution during covid-19 was a final assessment to determine whether it was competent or not competent yet. Furthermore, NY stated that the form of evaluation carried out was in the form of written tests and interviews. Another thing was revealed by $\mathrm{CC}$, he stated that participants were said to have passed if they were able to produce works independently according to the material being taught. The work is a manifestation of the results of direct practice according to theory and training modules. Based on WW's view, a trainee is said to have passed and is competent if he or she is able to take an exam from a Competency Certification Agency (Lembaga Sertifikasi Kompetensi) with a standard score. AR and MG stated that the evaluation they carried out was with a final competency test with scores, which in the end would all pass but with different scores. Unlike the other administrators, AM stated that participants were given an exam according to the chosen level and other tests in the form of an academic potential test.

\section{Discussion}

\section{Program Planning Management}

The strategy in the planning process of training programs during the pandemic requires managers to think creatively. This is because the training program is closely related to technical activities and must meet physically and then forced by circumstances to change to virtual. Effectiveness in training activities carried out virtually has proven to be less effective for several types of training. This is reinforced by studies which state that virtual learning has proven to be less effective and is in line with the lack of understanding of participants in the learning process (Rachmat \& Krisnadi, 2020). Furthermore, there are several points that are the main problems in virtual learning, namely the lack of mastery of technology, unstable signals, large budgets, and the potential for psychological diseases such as stress (Rasyida, 2020). To reduce problems in virtual learning, there are several activities that can be carried out, namely guidance and mentoring activities. The results of the study stated that $86.7 \%$ of the training participants needed guidance in mastering search engine tools such as Google and some of its derivative products. The use of these applications in virtual learning has a role as a communicator, facilitator, motivator, and mediator (Mulyanah \& Andriani, 2021). Furthermore, other research results state that in virtual training is as effective as face-to-face training if it is well prepared, even more efficient from the point of view of time and cost, but groups in the classroom show higher positive motivation regarding training activities than groups with virtual learning (Schmeeckle, 2003).

The planning process for the training program was also carefully structured, considering the people's purchasing power which continued to decline and they chose to use their expenditures only in important posts. The results of the study stated that the economic situation during the pandemic was quite sad, the losses were massive in 
various aspects, namely national, sectoral, corporate, and individual (Hadiwardoyo, 2020). A service-oriented economy is negatively affected. Countries that depend on the tourism sector (more than 15\% of GDP) are more affected by the pandemic crisis, in addition, countries that depend on foreign trade are more negatively affected. The results show that on average each additional month of crises consumes 2.5-3\% of global GDP (Fernandes, 2020). In more detail, COVID-19 has also had given economic impacts such as a slowdown in the production of goods, disrupting supply chains, losses in business, poor cash flow in the market, as well as a significant slowdown in revenue growth (Haleem et al., 2020). These results are sufficient to provide the fact that people will be very picky in spending their money. In line with this, training institutions should have their own strategies to maintain their existence.

The results of the interviews show that there are institutions that reform their training management by making programs that are limited in terms of time and participants. This makes operational costs decrease and the impact on prices borne by participants. The cost factor is one of the important factors in making a decision to choose/register an educational program (Sapitri \& Yaya, 2015). Furthermore, the cost factor is also an important factor in considering continuing studies (Syaifulloh et al., 2020). At the program planning stage, institutions must pay attention to health protocols if carried out face-to-face, the impact is that there is additional funding that must be budgeted which ultimately affects the price borne by participants. This shows that institutions must start shifting from face-to-face to virtual systems, even if they continue to use face-to-face, the portion can be shared virtually using blended learning. The size of the budget portion in implementing health protocols also increases the budget portion for training. In addition to learning governance reforms to lower the cost of training, strategies in the planning stages are related to marketing. The data states that in January 2021 internet users in Indonesia grew $73.3 \%$ or in total to around 202.6 million users, which previously was around 274.9 million users, furthermore, the fact that the time spent using the internet also increased from the average an average of 7 hours 59 minutes then increased to 8 hours 52 minutes with a $40 \%$ increase in network traffic with details on chat features as much as $96.5 \%$, social networking $96.3 \%$, shopping activities $78.2 \%$, finance $39.2 \%$, entertainment $86.2 \%$, and other services (Sutadi, 2021). The findings suggest that the future of marketing is in digital marketing, and companies are rapidly moving in that direction as consumers spend more time online. The study also found that the number of consumers who make online purchases continues to increase (Narkiniemi, 2013). This fact becomes an opportunity for marketing strategies through cyberspace such as using social media Instagram, Facebook, and other media. Apart from not having to print brochures and other marketing costs, marketing strategies through cyberspace are also considered very effective, although in fact it was also found that the utility of social media marketing has a significant impact on brand awareness building. But in social media marketing there are customer engagement and viral marketing variables that still require more attention, because it is known that the lack of online consumer involvement and the lack of content dissemination through social media do not help the industry in building or increasing understanding of a trademark (Adrian \& Mulyandi, 2021).

Another fact from the interviews showed that several institutions used the selection process in recruiting prospective trainees, but some did not. This is because 
each institution has its own considerations in the selection process which are related to funding, types of training, and business orientation. Whether or not the selection process for prospective trainees is important depends on the context, but the most important thing is the initial assessment process. The initial assessment process will also provide an overview of the abilities of prospective participants which can later be used for the effectiveness of the learning curriculum to be implemented. So that in the end the learning process that is arranged is more efficient in time and functional in content. The results of the study also indicated that participation in the initial assessment program reduced participants' average likelihood of needing a remedial examination by $6.1 \%$ in language and $4.1 \%$ in arithmetic (Howell et al., 2010).

\section{Program Implementation Management}

Such as learning in general, in the training process the interaction between tutors and participants is very important. The interaction between the tutor and the participants illustrates that the skill transfer process is going well. The importance of interaction in learning is illustrated by a study which states that educational interactions carried out by education to students have the potential to increase motivation in learning (Sudaningsih, 2020). In a pandemic atmosphere, the learning process in training requires adjustments, namely using digital platforms that aim to reduce face-to-face contact. This policy poses various weaknesses considering that some types of training do not allow full use of the virtual meeting. The results of the interview mentioned that several types of training that have high challenges if applied online are the type of training that is technical in nature and training related to self-development and motivation. Technical training requires a very high level of practical understanding, because it is related to dynamic activities. Self-development/motivation training also has its own challenges if it is carried out with a virtual system, considering that the activity process requires a high level of focus on the words conveyed by the tutor. Self-development/motivation training requires communication that is free from distractions. Based on the results of the study, it is stated that digital communication is very vulnerable to limitations in expressing nonverbal expressions and appearances (Nahwiyyah \& Dewi, 2020). For types of training that are not technical in nature, it is better to use virtual learning or mixed learning, this is because the pandemic condition requires quite serious handling.

\section{Program Evaluation Management}

Competent or not someone who has been given the material is determined one of them by the evaluation process. The form of evaluation is adjusted to the rules of the institution and the type of training provided. The purpose of the evaluation includes the meaning of something to be achieved on the contrary in the task of proving the role carried out in order to achieve the goal. The conditions are that the assessment must actually use measuring equipment that is appropriate (valid) according to its purpose, the test equipment must be reliable or produce the same results (not changing), and the last assessment provision is that the assessment must be instant or easy to use (Suardipa \& Primayana, 2020). The results of interviews conducted with the training manager stated that there are various types of evaluations at each institution. There are institutions that provide evaluations in the form of tests and interviews, examinations from certification institutions, and other specified forms. In a pandemic, evaluation 
activities in training have big challenges. Apart from the limitations in technical assessment by assessors, the process of evaluation activities is also prone to fraud committed by participants. Based on the results of the study, the evaluation process during the pandemic is better directed to a contextual evaluation provided that it uses valid, reliable, consistent and practical measuring tools.

\section{CONCLUSION}

The education and training strategy during the covid-19 pandemic to maintain the existence of the institution and continue to provide benefits is carried out as follows: 1) at the planning stage of the course and training institution changing the time, goals, and costs to adjust to the pandemic conditions, then making a digital marketing strategy, and initial assessment for material efficiency; 2) at the implementation stage, the institution applies virtual learning, as well as face-to-face if it is really necessary to do so; 3 ) at the evaluation stage, the institution uses a contextual evaluation adapted to the pandemic situation but with the appropriate conditions. All efforts made by course and training institutions in the context of adjusting to the pandemic situation. The principle is that the community is still served the need for training and improving their skills, on the other hand the institution can still carry out its institutional governance, and far more important both the participants and the manager of the training institution remain in good health.

\section{REFERENCES}

Adrian, D., \& Mulyandi, M. R. (2021). Manfaat Pemasaran Media Sosial Instagram Pada Pembentukan Brand Awareness Toko Online. Jurnal Indonesia Sosial Sains, 2(2), 215-222.

Fernandes, N. (2020). Economic Effects of Coronavirus Outbreak (COVID-19) on the World Economy. SSRN Electronic Journal. https://doi.org/10.2139/ssrn.3557504

Hadiwardoyo, W. (2020). Kerugian Ekonomi Nasional Akibat Pandemi Covid-19. Baskara: Journal of Business and Entrepreneurship, 2(2), 83-92.

Howell, J. S., Kurlaender, M., \& Grodsky, E. (2010). Postsecondary preparation and remediation: Examining the effect of the Early Assessment Program at California State University. Journal of Policy Analysis and Management, 29(4), 726-748.

Mulyanah, N., \& Andriani, A. (2021). Strategi Bimbingan dan Pelatihan Guru Dalam Pembelajaran Menggunakan Aplikasi Google Pada Pembelajaran Daring Untuk Meningkatkan Efektifitas Belajar Siswa Dimasa Pandemi Covid-19. Jurnal Riset Pendidikan Dasar (JRPD), 2(1), 67-73.

Nahwiyyah, R., \& Dewi, E. N. (2020). Fungsi Emoticon Sebagai Bahasa Nonverbal Dalam Komunikasi Digital. PRoListik: Jurnal Ilmu Komunikasi, 5(2).

Narkiniemi, J. (2013). Using Digital Marketing to Develop a Modern Marketing Strategy for a Startup.: Case study: Design With Benefits [Helsinki Metropolia University of Applied Sciences]. https://www.theseus.fi/handle/10024/67988

Olagbaju, O. O., Awosusi, O. E., \& Shaib, O. E. (2020). COVID-19 Induced Changes on Lifestyles Education and Socio-Economic Activities in West African States: Recovery Strategies for Post Pandemic Era. International Journal of World 
Policy and Development Studies, 64, 38-43. https://doi.org/10.32861/ijwpds.64.38.43

Pranoto, S. A., Wahida, A., \& Kurniadi, E. (2021). Peranan Manajemen Pengelolaan Pendidikan Non Formal Untuk Mempertahankan Eksistensi Pada Masa Pandemi Covid-19. SENADA (Seminar Nasional Desain Dan Arsitektur), 4, 374-379.

Rachmat, A., \& Krisnadi, I. (2020). Analisis Efektifitas Pembelajaran Daring (Online) Untuk Siswa SMK Negeri 8 Kota Tangerang Pada Saat Pandemi Covid 19. Magister Teknik Elektro Universitas Mercu Buana, 1-7.

Rasyida, H. (2020). Efektivitas Kuliah Daring Di Tengah Pandemik. Jurnal Edukasi, $1(1), 1-8$.

Sapitri, Z., \& Yaya, R. (2015). Faktor-faktor yang berpengaruh terhadap minat mahasiswa untuk mengikuti Pendidikan Profesi Akuntansi (PPAk). Journal of Accounting and Investment, 16(1), 46-61.

Schmeeckle, J. M. (2003). Online training: An evaluation of the effectiveness and efficiency of training law enforcement personnel over the internet. Journal of Science Education and Technology, 12(3), 205-260.

Suardipa, I. P., \& Primayana, K. H. (2020). Peran desain evaluasi pembelajaran untuk meningkatkan kualitas pembelajaran. Widyacarya: Jurnal Pendidikan, Agama Dan Budaya, 4(2), 88-100.

Sudaningsih, I. V. (2020). Interaksi Edukatif antara Pendidik dan Peserta Didik untuk Meningkatkan Motivasi Belajar Bahasa Inggris. Seminar Nasional Pendidikan, $1(1)$, 300-309. https://jurnal.ustjogja.ac.id/index.php/semnas2020/article/view/7544/3480

Sutadi, H. (2021, February 26). Pandemi dan Meningkatnya Kebutuhan Akses Data Internet. kontan.co.id. https://adv.kontan.co.id/news/pandemi-danmeningkatnya-kebutuhan-akses-data-internet

Syaifulloh, M., Wahana, A. N. P. D., \& Riono, S. B. (2020). Imbas Biaya Pendidikan Terhadap Minat Studi Lanjut Di Perguruan Tinggi Kabupaten Brebes. Syntax Idea, 2(4), 92-98. 
AKSARA: Jurnal Ilmu Pendidikan Nonformal

P-ISSN 2407-8018 E-ISSN 2721-7310 DOI prefix 10.37905

Volume 07, Issue 03 September 2021

http://ejurnal.pps.ung.ac.id/index.php/Aksara

864 AKSARA: Jurnal Ilmu Pendidikan Nonformal 